\title{
New Molecular Approaches in the Diagnosis and Prognosis of Thyroid Cancer Patients
}

\author{
Enke Baldini ${ }^{1}$, Chiara Tuccilli ${ }^{1}$, Natalie Prinzi $^{1}$, Salvatore Sorrenti ${ }^{2}$, Marta Bianchini ${ }^{1}$, \\ Marianna Del Sordo ${ }^{1}$, Stefania Alessandrini ${ }^{1}$, Renzo Mocini ${ }^{2}$ and Salvatore Ulisse ${ }^{1, *}$ \\ ${ }^{1}$ Department of Experimental Medicine, "Sapienza" University of Rome, Italy \\ ${ }^{2}$ Department of Surgical Sciences, "Sapienza” University of Rome, Italy
}

\begin{abstract}
Thyroid nodules are very common in the adult population, but only a minority of them harbor a malignant lesion. Therefore, the first aim in their clinical evaluation is to exclude malignancy. To date, the fine-needle aspiration cytology (FNAC) represents the main diagnostic tool for the evaluation of thyroid nodules and cervical lymph nodes (CLN) suspected of metastatic disease. It has to be mentioned, however, that FNAC on thyroid nodules suffers from a major diagnostic limit represented by cellular atypias of indeterminate significance, which require the histological diagnosis. Also the FNAC performed on CLN may be a challenging diagnostic category as CLN could harbor metastases from a multiplicity of extrathyroidal malignancies or be affected by several non-tumoral diseases. In addition, inadequate cellularity obtained from both thyroid nodules or CLN prevents diagnosis in about $20 \%$ of specimens.

Total thyroidectomy followed by adjuvant therapy with ${ }^{131} \mathrm{I}$ is the treatment of choice for most patients affected by DTC. Although the prognosis of DTC patients is favorable, about $20 \%$ of them face the morbidity of disease recurrence and tumor-related deaths. Thus far, the prognosis of these patients still relies on clinic-pathological variables such as patient's age, tumor size, histology, lymph node or distant metastasis, which are not accurate in predicting the long-term outcome. As a consequence, the identification of new molecular biomarkers strictly related to the risk of DTC relapse is highly needed.
\end{abstract}

In the present review we'll attempt to summarize the recent characterization of new molecular markers able to ameliorate the diagnosis and prognosis of thyroid cancer patients.

Keywords: BRAF, Estrogen receptor, Calcitonin, Cervical lymph node, Gene expression, miRNA, TNM, Thyroglobulin, Urokinase plasminogen activating system.

\section{THYROID CANCER OVERVIEW}

Tumors derived from the follicular thyroid cell are the most frequent endocrine malignancy representing in the United States the fifth most common cancer in women [1, 2]. Its annual incidence, about $2.5 \%$, increased over the last two decades, mainly because of the improved ability to diagnose malignant transformation in small non-palpable thyroid nodules [3, 4]. The large majority of epithelial thyroid cancers is represented by the differentiated papillary (PTC) and follicular (FTC) thyroid carcinomas which, following dedifferentiation, are thought to give rise to the highly aggressive and incurable anaplastic thyroid carcinomas (ATC) [5, 6]. Although derived from the same cell type, the different thyroid tumors show specific histological features, biological behavior and degree of differentiation as a consequence of different genetic alterations [7, 8]. In particular, early genetic mutations in thyroid cancer comprise gene rearrangements of tyrosine kinase receptors, such as the RET/PTC and NTRK1 (neurotrophic receptor-tyrosine kinase 1), or

*Address correspondence to this author at the Department of Experimental Medicine, "Sapienza" University of Rome, Viale Regina Elena, 324, 00161Rome, Italy; Tel: +39-0649972607; Fax: +39-0649972606;

E-mail: salvatore.ulisse@uniroma1.it activating point mutations of proteins mediating cellular responses to growth and differentiation signals, including RAS and BRAF, or the oncogenic fusion protein PAX8-PPAR $\gamma$, that suppresses wild-type PPAR $\gamma$ function in a dominant-negative manner [7, 8]. Importantly, the conversion of early-stage thyroid tumors to more aggressive and invasive malignancies occurs through an epithelial-to-mesenchymal transition (EMT), which implies the loss of cell-cell contacts, remodeling of cytoskeleton, and the acquisition of a migratory phenotype $[9,10]$. In fact, genetic alterations of integrins, Notch, MET, TGF $\beta$, NF-KB, PI3K, TWIST1 and p21-activated kinase (Pak), related to the EMT, have been identified in PTC progression [10-12].

Thyroid nodules are very common, affecting $19 \%$ to $67 \%$ of the adult population, but only about $5 \%$ of them harbor a malignant lesion [13, 14]. Therefore, the first aim in the clinical evaluation of a thyroid nodule is to exclude malignancy [15]. To date, fine-needle aspiration cytology (FNAC) represents the main diagnostic tool for the evaluation of both palpable and non-palpable thyroid nodules. It has to be mentioned, however, that FNAC suffers from a major diagnostic limit represented by follicular lesions (Thy3), in which the encountered cellular atypias are of indeterminate significance $[15,16]$. In this context, we'll below 
describe new molecular approaches claimed to ameliorate the diagnosis of these patients. Also the accurate diagnosis of cervical lymph node metastasis, which is of primary importance for the initial surgical approach as well as for prognostic stratification and follow-up of thyroid cancer patients, relies on FNAC [17-20]. The latter, however, crucially depends on the experience and ability of the cytopathologist, and may be a challenging diagnostic category as CLN could harbor metastasis from a multiplicity of extrathyroidal malignancies or be affected by several non-tumoral diseases [21, 22]. In addition, inadequate cellularity or non-representative sampling, often associated with cystic lymph nodes, prevents diagnosis in about $20 \%$ of specimens [23, 24]. Below we'll discuss as the molecular diagnosis performed in the CLN washout may increase the diagnostic accuracy of FNAC.

Total thyroidectomy followed by adjuvant therapy with ${ }^{131} \mathrm{I}$ is the treatment of choice for most patients affected by differentiated thyroid carcinoma (DTC) [1, 13-16]. After that, patient's follow-up includes radioiodine scanning 6-12 months after surgery, periodic ultrasound of the thyroid bed and cervical lymph node compartments, measurement of basal and recombinant human TSH-stimulated thyroglobulin serum level [1, 13-15]. Although the prognosis of patients with DTC is favorable, with 10-years-survival rate of nearly $90 \%$, about $20 \%$ of patients face the morbidity of disease recurrence and deaths $[1,2,15$, 25]. The latter, in particular, are observed in patients with poorly differentiated thyroid cancer (PDTC) or ATC $[7,25,26]$. As a consequence, new therapeutic approaches for the most aggressive thyroid cancers are still urgently needed [27-31]. Despite the increasing knowledge of the molecular processes responsible for thyroid cell malignant transformation and cancer progression, to date, the prognosis of thyroid cancer patients still relies on high-risk clinic-pathological variables such as patient's age, tumor size, histology, lymph nodal or distant metastasis [32, 33]. As a consequence, the identification of molecular biomarkers strictly related to the risk of PTC relapse represents an attractive gain $[34,35]$. Below we'll summarize recent findings describing the potential prognostic value of different new molecular markers able to refine the prognostic stratification of thyroid cancer patients [34, 35].

\section{NEW MOLECULAR APPROACHES IN THE DIAGNOSIS OF THYROID NODULES}

FNAC represents the gold standard in the diagnosis of thyroid nodules because of its diagnostic accuracy, reproducibility and cost effectiveness $(15,16)$. In particular, FNAC based diagnosis of thyroid nodules is characterized by a sensitivity of $65-98 \%$, specificity of $72-100 \%$ and accuracy of $84-95 \%$ [36-38]. The Bethesda System for reporting thyroid cytopathology classifies the FNAC outcome in 6 diagnostic categories including: 1) non-diagnostic; 2) benign; 3) atypia/follicular lesion of undetermined significance; 4) follicular neoplasm or suspicious for follicular neoplasm; 5) suspicious for malignancy; 6) malignant $[39,40]$. While FNAC diagnosis is very reliable for PTC and ATC, the diagnostic categories 3 to 5 represent a grey zone in which the cytology cannot discriminate malignant (i.e. follicular carcinoma and follicular variant of papillary carcinoma) from benign (i.e. follicular adenoma and nodular adenomatous goiter) tumors [38]. Consequently, in presence of nodules with indeterminate cytology, thyroidectomy is usually required because only the histological evaluation of capsular and vascular invasion can differentiate these neoplasms. Based on histological outcome the category atypia/follicular lesion shows a malignancy risk of $5-15 \%$, that of follicular neoplasm or suspicious for follicular neoplasm of $15-35 \%$, and that of suspicious for malignancy of $60-75 \%$. As a consequence, a consistent number of patients is actually facing needless thyroid surgery. Thus, the identification of parameters related to malignancy is strongly required to avoid morbidity and costs associated to unnecessary surgery. Several alternative diagnostic approaches were put forward in order to overcome the diagnostic boundaries of FNAC, including patient's clinical characteristics, ultrasonography (US) parameters, radionuclide scanning with technetium-99m, positron-emission tomography and identification of single genetic alterations in fine-needle aspiration material. To date, however, none of them turned out to improve significantly the pre-surgical selection of nodules with indeterminate cytology [38-53].

Over the last few years, two different new molecular approaches were proposed to evaluate FNA samples $[54,55]$. The first one, introduced by Nikiforov and colleagues, suggested to differentiate benign from malignant nodules based on the detection in FNA samples of the seven most common proto-oncogene mutations encountered in PTC and FTC, namely RET/PTC1, RET/PTC3, BRAF ${ }^{\mathrm{V} 600 E}$, HRAS (codon 61), KRAS (codon 12 and13), NRAS (codon 61) and PAX8/PPAR $\gamma$ [56-59]. It has to be noted in fact that, with the exclusion of RAS, mutation tests for each of these genes possess a very high predictive value for 
malignancy. In the larger prospective study, including 1056 consecutive FNA samples with indeterminate cytology, these authors showed that $87-95 \%$ of mutation positive samples with indeterminate cytology were malignant at histology (see Table $\mathbf{1}$ for sensitivity, specificity, negative and positive predictive values and accuracy for the different diagnostic categories) [57]. The false positive results were represented by 9 RAS mutation positive samples, which turned to be benign (follicular adenoma) on histological examination. The latter results are still acceptable since follicular adenomas carrying RAS mutation are considered premalignant lesions $[57,59]$. Less acceptable is the relative high percentage of false negative results, ranging from $32 \%$ to $43 \%$ in the 3 different diagnostic categories with indeterminate cytology, responsible for the low sensitivity observed (Table 1).

These results could have been expected since the proto-oncogene mutations analyzed are held responsible for about $60-70 \%$ of all DTC, while the remaining do not show recognized somatic gene alterations. The second approach, named geneexpression classifier (GEC), was intended to identify benign, rather than malignant, thyroid nodules with the main aim to reduce unnecessary thyroid surgery in patients with indeterminate cytology [60-62]. The GEC, called Afirma and developed by Veracyte Inc. (San Francisco, CA), consists of a microarray analyzing the expression of 167 different genes in the RNA extracted from FNA biopsies [60]. Alexander and colleagues in a prospective multicenter study validated the method on a case study of 265 nodules with indeterminate cytology [61]. As expected for a test designed to identify benign samples, the negative predictive value ranged between $85 \%$ and $95 \%$ in the three diagnostic categories with indeterminate cytology (see Table 1). As for the proto-oncogene mutation test, a major caveat rising from the results of this study was that as many as 6 to $18 \%$ of nodules classified as benign by the GEC (false negative) were likely to harbor a malignant lesion [61]. To overcome these limitations it was also thought that combining a high specific genetic mutation test, such as the $\mathrm{BRAF}^{\mathrm{VGO0E}}$ one, with the highly sensitive GEC test, could lead to a better discrimination of malignant from benign lesions in nodules with indeterminate cytology [63]. The results of such attempt were recently reported by Kloos and colleagues, who analyzed 208 nodules with indeterminate cytology and found that the analysis of $\mathrm{BRAF}^{\mathrm{V} 600 \mathrm{E}}$ did not improve the diagnostic accuracy of the GEC alone [64].

In conclusion, while the two diagnostic methods above described represent an improvement of the molecular diagnosis of thyroid nodules they still present important caveats which limit at the moment their clinical application. It is possible that in a near future the identification of additional genes involved in thyrocyte malignant transformation may improve the diagnostic accuracy of the proto-oncogene mutation test, as well as the implementation of the GEC with additional genes such as miRNAs, thought to play a role in cell transformation and cancer progression, may increase the test predictivity $[54,55,65]$.

\section{MOLECULAR DIAGNOSIS IN CERVICAL LYMPH NODES}

As above mentioned, the accurate diagnosis of loco-regional lymph node metastasis is of primary importance for the initial surgical approach as well as for prognostic stratification and follow-up of thyroid cancer patients $[15,17-21,66,67]$. The FNAC represents the gold standard technique for the diagnosis of CLN suspected to harbor metastatic disease from thyroid cancer as well as from other primary tumors $[15,17-21,66]$. The technique accuracy, highly dependent on the experience and

Table 1: Diagnostic Performance of the Proto-Oncogene Mutation and Gene-Expression Classifier Tests in the Diagnosis of Thyroid Nodules with Indeterminate Cytology

\begin{tabular}{|c|c|c|c|c|c|}
\hline $\begin{array}{l}\text { Proto-oncogene mutations (ref. [56]) } \\
\text { Atypia/follicular lesion of undetermined significance } \\
\text { Follicular /suspicious for follicular neoplams } \\
\text { Suspicious for malignancy }\end{array}$ & $\begin{array}{l}63 \% \\
57 \% \\
68 \%\end{array}$ & $\begin{array}{l}99 \% \\
97 \% \\
96 \%\end{array}$ & $\begin{array}{l}94 \% \\
86 \% \\
72 \%\end{array}$ & $\begin{array}{l}88 \% \\
87 \% \\
95 \%\end{array}$ & $\begin{array}{l}94 \% \\
86 \% \\
81 \%\end{array}$ \\
\hline $\begin{array}{l}\text { Gene-expression classifier (ref. [59]) } \\
\text { Atypia/follicular lesion of undetermined significance } \\
\text { Follicular / suspicious for follicular neoplams } \\
\text { Suspicious for malignancy }\end{array}$ & $\begin{array}{l}90 \% \\
90 \% \\
94 \%\end{array}$ & $\begin{array}{l}53 \% \\
49 \% \\
52 \%\end{array}$ & $\begin{array}{l}95 \% \\
94 \% \\
85 \%\end{array}$ & $\begin{array}{l}38 \%{ }^{*} \\
37 \% \\
76 \%\end{array}$ & $\begin{array}{l}62 \%{ }^{*} \\
59 \% \\
78 \%\end{array}$ \\
\hline
\end{tabular}

NPV, negative predictive value; PPV, positive predictive value. "Calculated from data reported in reference [59]. 
ability of the cytopathologist, has been reported to vary from $73 \%$ to $94 \%$ [68-71]. A major limitation to FNAC is represented by the inadequate cellularity or nonrepresentative sampling often associated with cystic lymph nodes which prevents diagnosis in about $20 \%$ of specimens [23, 24]. In order to solve this diagnostic caveat, in 1992 Pacini and colleagues first described the utility of thyroglobulin $(\mathrm{Tg})$ protein measurement in the washout of the needle used for the FNAC [72]. In this initial study they reported that $\mathrm{Tg}$ detection in fine needle aspirates of non-thyroidal neck masses showed $100 \%$ sensitivity in detecting CLN metastasis during the follow-up of patients who were previously treated by total thyroidectomy and ${ }^{131}$ I ablation, while FNAC alone showed a sensitivity of $85 \%$ [72]. Since then, different studies, measuring Tg protein and/or mRNA, confirmed the utility of $\mathrm{Tg}$ determinations in the detection of DTC metastasis in CLN [67-71, 73-81]. It is worth noting that, differently from serum $\mathrm{Tg}$ measurement, $\mathrm{Tg}$ detection in the washout of fineneedle aspirates from CLN is not affected by circulating anti-Tg antibodies present in about $20 \%$ of patients affected by DTC [82]. In addition, the same technique may be used to detect calcitonin (CT) protein and/or mRNA for the detection of metastatic medullary thyroid cancer (MTC) [81]. The diagnostic performance of this molecular approach, in terms of sensitivity, specificity, negative and positive predictive value and accuracy was shown to be excellent [67-82]. Based upon these pieces of evidence, the routine association of $\mathrm{Tg}$ protein detection with FNAC in the preoperative diagnosis of suspicious CLN was recommended [17,
18]. However, in a recent study, we showed that the diagnostic accuracy of $\mathrm{Tg}$ determination, although excellent, was not statistically superior to that of FNAC alone, nor the combination of the two tests improved the diagnostic accuracy of FNAC alone [81]. However, we found that $\mathrm{Tg}$ and $\mathrm{CT}$ detection in suspicious metastatic CLN was of clinical value in cases in which FNAC provided uninformative diagnosis, as often occur in presence of cystic lymph nodes, or when FNAC diagnosis is inconsistent with respect to patient's biochemical and/or clinical parameters [67, 81]. Following these observations we proposed that samples for $\mathrm{Tg}$ and CT mRNA and protein analysis from CLN suspicious for metastatic thyroid cancer should be always collected, but their measurements should be restricted to cases in which FNAB-C gives uninformative or inconsistent diagnosis with respect to patient's biochemical and/or clinical parameters (see the flow chart in Figure 1).

It is also worth to mention that this approach may significantly reduce the costs of the management of patients with thyroid cancer whose incidence, as above described, has been increasing over the last years being actually the fifth most common cancer in women.

\section{NEW EMERGING PROGNOSTIC MOLECULAR MARKERS IN THYROID CANCER PROGNOSIS}

The most widely used staging system for thyroid cancer patients is represented by the TNM (Iumor size, lymph Node and distant Metastasis) system

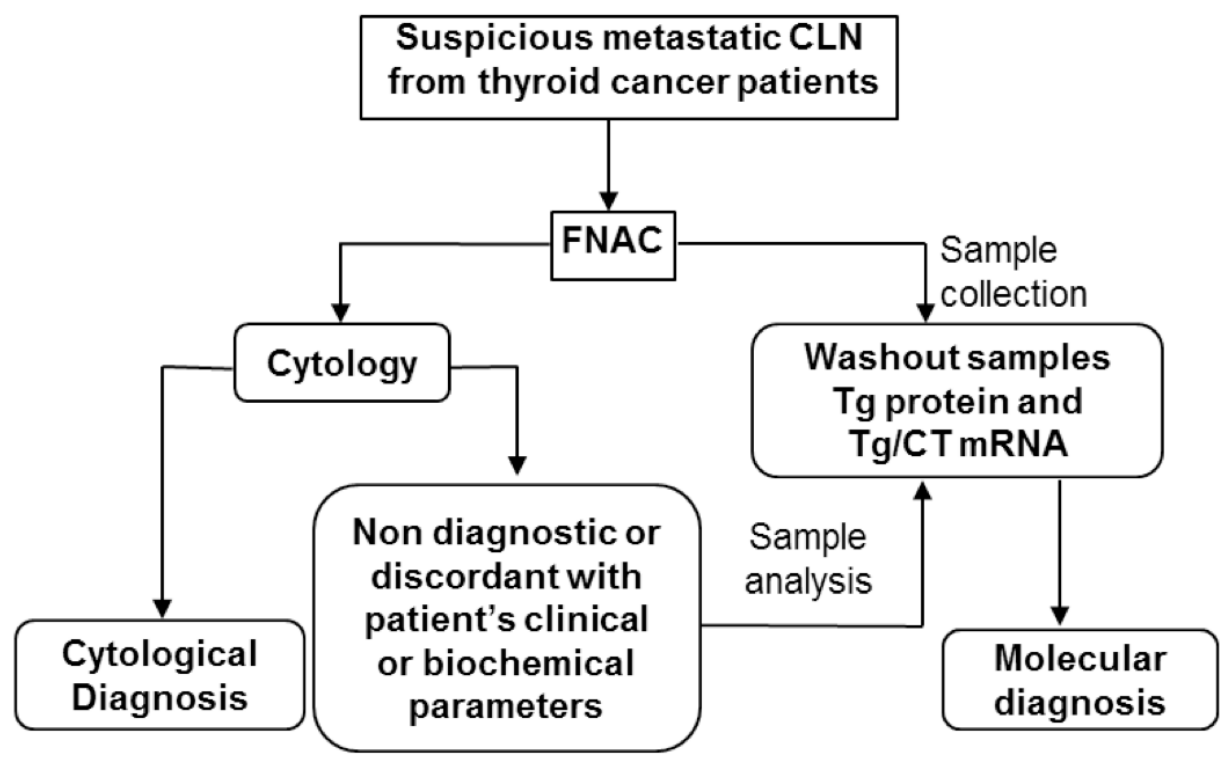

Figure 1: flow-chart for diagnosis of suspicious metastatic cervical lymph nodes (CLN) from thyroid cancer patients (adapted from BMC Clinical Pathology 2013;13:7). Following fine-needle aspiration cytology (FNAC) samples for Tg protein and Tg/CT mRNA measurements should be collected, but their analysis restricted to cases with uninformative or clinically unsound FNAC diagnosis. Tg, thyroglobulin; CT, calcitonin. 
developed by the American Joint Committee on Cancer and the International Union Against Cancer [83]. This staging system is strongly influenced by the patient's age with those above $45 \mathrm{yr}$ receiving a worse prognosis despite other factors being equal [83]. The TNM, as well as other staging systems proposed by recognized international organizations, are capable to make a rough prediction of the high or low risk of cancer mortality leaving, however, in the same risk group patients showing different disease-specific progression and survival time. Similarly, they fail to predict the risk of cancer recurrences [84]. Regarding the latter, both the European (ETA) and the American Thyroid Associations (ATA) proposed practical guidelines to estimate the risk of recurrences in which the TNM parameters are integrated by additional clinical features such as the tumor histological variant, the results of post-ablative whole body scan and the serum $\mathrm{Tg}$ levels $[15,18]$. Despite that, patients included in the same risk group showed a very heterogeneous behavior in terms of disease-free interval. In addition, the stratification risk proposed by the ATA and the ETA is not accurate in predicting the long-term outcome in differentiated thyroid cancer patients, showing a very low positive predictive value [85]. As a consequence, the identification of new prognostic molecular biomarkers able to testify tumor aggressiveness is required.

In this context, BRAF ${ }^{\mathrm{V} 600 \mathrm{E}}$ mutation, the most prevalent genetic alteration observed in $29-87 \%$ of PTC, received considerable attention as new prognostic marker in PTC $[86,87]$. In fact, several reports showed the association of this mutation with factors related to poor prognosis, such as the presence of extrathyroidal extension, lymph node metastasis, advanced tumor stage, reduced disease-free interval and patient survival [86, 87]. However, despite the initial enthusiasm, a debate is ongoing about the clinical relevance of these findings $[86,87]$. In particular, further studies failed to associate the BRAF $^{\mathrm{V} 600 \mathrm{E}}$ with poor prognosis in PTC patients [88-92]. In addition, the frequency of BRAF mutation in PTC is high (about 50\%), compared with the poor outcomes (about 20\%), and as a consequence a large percentage of patients would face the risk of over- or under-treatment based only on the analysis of the BRAF $^{\mathrm{V} 600 \mathrm{E}}$ mutation [87].

Over the last few years, our and other research groups investigated the prognostic value of the components of the urokinase plasminogen activating system (UPAS) in thyroid cancer patients [91, 93-108]. The UPAS consists of the urokinase plasminogen activator (UPA), its cognate cell membrane receptor (UPAR) and two main inhibitors, the plasminogen activator inhibitor-1 (PAl-1) and -2 (PAI-2) [109]. It controls several pathophysiological processes, including human cancer progression where induces extracellular matrix degradation, activation of latent growth factors, malignant cells proliferation and spread and tumor neo-angiogenesis $[109,110]$. The prognostic value of UPAS components was validated for different cancer types and, as a rule, overexpression of one or more uPAS components was shown to associate with a higher risk of relapse and poor clinical outcome [109, 110]. This is particularly evident in breast cancer, in which UPA and PAI-1 were shown to be among the most potent prognostic factors described to date, with a predictive value stronger than those of patient age, tumor size, estrogen and progesterone receptors, HER-2/neu or p53 expression [111-115]. This evidence led the American Society of Clinical Oncology to include both UPA and PAI-1 among the recommended breast tumor markers for clinical use [116]. Also in PTC, over-expression of UPA and UPAR significantly associates with high-risk clinicopathological factors such as lymph node metastasis, higher TNM stage and lower disease-free interval [91, 93-95]. In addition, Horvatić Herceg and colleagues on a case study of patients with benign and malignant thyroid cancers, including PTC, FTC, MTC and ATC, showed that high expression of UPA and PAI-1 associated with tumor size, extrathyroidal invasion, lymph node and distant metastasis, and progression-free survival [96]. All together, the above findings warrant further investigation to confirm the potential role of UPAS components in thyroid cancer prognosis.

Very recently, two new molecular markers potentially useful for the prognosis of thyroid cancer patients were described $[92,117]$. The first is represented by the estrogen receptor (ER) shown to possess a prognostic value in several cancer types including breast, ovarian and lung cancers [118-123]. In particular, an elevated level of ER $\alpha$ expression is associated with an improved survival in breast and ovarian cancer patients, but with reduced survival in lung cancer, while the low expression of ER $\beta$ associates with a poor survival in ovarian, breast and lung cancer patients [118-123]. In a recent study Heikkilä and colleagues demonstrated that the reduction of ER $\beta$ expression associates significantly with poor outcome in FTC patients [117].

The second one is represented by the miR-146b [92]. MicroRNA (miR) are small (19-25 nucleotides), 
noncoding RNA molecules that behave as negative regulators of gene expression [124]. They regulate important cellular functions as proliferation and apoptosis and may act as tumor suppressor genes and oncogenes [124]. Mature miRs typically down-regulate gene expression post-transcriptionally by inhibiting mRNA translation or promoting mRNA degradation by annealing to complementary sequences in $3^{\prime}$ untranslated regions of their target mRNAs [124]. In thyroid cancer tissues different miRs were found upregulated and a number of them were suggested to have a diagnostic utility $[65,125]$. One of them, the miR-146b, was shown to associate in PTC with extrathyroidal invasion, advanced tumor stage, BRAF mutation and disease-free survival $[92,126]$.

In conclusion, a number of new molecular markers potentially capable to predict disease outcome in thyroid cancer patients is emerging. The reported evidence warrant for each of them further clinical investigation in larger prospective multicenter trials to definitely prove their ability to predict disease outcome. This is likely to ameliorate the actual staging system thus allowing a tailored therapy and follow-up to the single patient needs.

\section{REFERENCES}

[1] Sherman SI. Thyroid carcinoma. Lancet 2003; 361: 501-11. http://dx.doi.org/10.1016/S0140-6736(03)12488-9

[2] Jemal A, Siegel R, Ward E, Hao Y, Xu J, Thun MJ. Cancer Statistics, 2009. Ca Cancer J Clin 2009; 59: 225-49. http://dx.doi.org/10.3322/caac.20006

[3] Trimboli P, Ulisse S, Graziano FM, Marzullo A, Ruggieri M, Calvanese A, et al. Trend in thyroid carcinoma size, age at diagnosis, and histology in a retrospective study of 500 cases diagnosed over 20 years. Thyroid 2006; 16: 1151-5. http://dx.doi.org/10.1089/thy.2006.16.1151

[4] Davies L, Welch HG. Increasing incidence of thyroid cancer in the Uited States, 1973-2002. JAMA 2006; 295: 2164-7. http://dx.doi.org/10.1001/jama.295.18.2164

[5] Kinder BK. Well differentiated thyroid cancer. Curr Opin Oncol 2003; 15: 71-7.

http://dx.doi.org/10.1097/00001622-200301000-00011

[6] Pasieka JL. Anaplastic thyroid cancer. Curr Opin Oncol 2003; 15: 78-83.

http://dx.doi.org/10.1097/00001622-200301000-00012

[7] Nikiforov YE. Diagnostic pathology and molecular genetics of the thyroid. Philadelphia: Lippincott Williams \& Wilkins 2009.

[8] Paschke R, Hegedüs L, Alexander E, Valcavi R, Papini E, Gharib $H$. Thyroid nodule guidelines: agreement, disagreement and need for future research. Nat Rev Endocrinol 2011; 7: 354-61. http://dx.doi.org/10.1038/nrendo.2011.1

[9] Motti ML, Califano D, Troncone G, De Marco C, Migliaccio I, Palmieri $\mathrm{E}$, et al. Complex regulation of the cyclin-dependent kinase inhibitor p27kip1 in thyroid cancer cells by the PI3K/AKT pathway: regulation of p27kip1 expression and localization. Proc Natl Acad Sci USA 2007; 104: 2803-8.
Huber MA, Kraut N, Beug $\mathrm{H}$. Molecular requirements for epithelial-mesenchymal transition during tumor progression. Curr Opin Cell Biol 2005; 17: 548-58. http://dx.doi.org/10.1016/j.ceb.2005.08.001

[11] Vasko V, Espinosa AV, Scouten W, He $H$, Auer $H$, Liyanarachchi $S$, et al. Gene expression and functional evidence of epithelial-to-mesenchymal transition in papillary thyroid carcinoma invasion. Proc Natl Acad Sci USA 2007; 104: 2803-8.

http://dx.doi.org/10.1073/pnas.0610733104

[12] Salerno P, Garcia-Rostan G, Piccinin S, Bencivenga TC, Di Maro G, Doglioni $\mathrm{C}$, et al. TWIST1 plays a pleiotropic role in determining the anaplastic thyroid cancer phenptype. J Clin Endocrinol Metab 2011; 96: E772-81. http://dx.doi.org/10.1210/jc.2010-1182

[13] Roman SA. Endocrine tumors: evaluation of the thyroid nodule. Curr Opin Oncol 2003; 15: 66-70. http://dx.doi.org/10.1097/00001622-200301000-00010

[14] Welker MJ, Orlov D. Thyroid nodules. Am Fam Phys 2003; 67: 559-66.

[15] American Thyroid Association (ATA) Guidelines Taskforce on Thyroid Nodules and Differentiated Thyroid Cancer, Cooper DS, Doherty GM, Haugen BR, Kloos RT, Lee SL, et al. Revised American Thyroid Association management guidelines for patients with thyroid nodules and differentiated thyroid cancer. Thyroid 2009; 19: 1167-14. http://dx.doi.org/10.1089/thy.2009.0110

[16] Nikiforov YE, Nikiforova MN. Molecular genetics and diagnosis of thyroid cancer. Nat Rev Endocrinol 2011; 7: 569-80.

http://dx.doi.org/10.1038/nrendo.2011.142

[17] Schlumberger M, Berg G, Cohen O, Duntas L, Jamar F, Jarzab B, et al. Follow-up of low-risk patients with differentiated thyroid carcinoma: a European perspective. Eur J Endocrinol 2004; 150: 105-12. http://dx.doi.org/10.1530/eje.0.1500105

[18] Pacini F, Schlumberger M, Dralle H, Elisei R, Smit JW, Wiersinga W. European Thyroid Cancer Taskforce: European consensus for the management of patients with differentiated thyroid carcinoma of the follicular epithelium. Eur J Endocrinol 2006; 154: 787-803. http://dx.doi.org/10.1530/eje.1.02158

[19] Cervin JR, Silverman JF, Loggie BW, Geisinger KR Virchow's node revisited. Analysis with clinicopathologic correlation of 152 fine-needle aspiration biopsies of supraclavicular lymph nodes. Arch Pathol Lab Med 1995; 8: 727-30.

[20] Stack BC Jr, Ferris RL, Goldenberg D, Haymart M, Shaha A Sheth S, et al. American Thyroid Association Surgical Affairs Committee: American thyroid association consensus review and statement regarding the anatomy, terminology, and rationale for lateral neck dissection in differentiated thyroid cancer. Thyroid 2012; 22: 501-8.

http://dx.doi.org/10.1089/thy.2011.0312

[21] Florentine BD, Staymates B, Rabadi M, Barstis J, Black A Cancer Committee of the Henry Mayo Newhall Memorial Hospital: The reliability of fine-needle aspiration biopsy as the initial diagnostic procedure for palpable masses: a 4-year experience of 730 patients from a community hospital-based outpatient aspiration biopsy clinic. Cancer 2006; 107: 406-16. http://dx.doi.org/10.1002/cncr.21976

[22] Cignarelli M, Triggiani V, Ciampolillo A, Ambrosi A, Giorgino $\mathrm{F}$, Liso $\mathrm{V}$, et al. High frequency of incidental diagnosis of extrathyroidal neoplastic diseases at the fine-needle aspiration biopsy of laterocervical lymph nodes in patients with thyroid nodules. Thyroid 2001; $11: 65-71$. http://dx.doi.org/10.1089/10507250150500685

[23] Ustün M, Risberg B, Davidson B, Berner A. Cystic change in metastatic lymph nodes: A common diagnostic pitfall in 
fine-needle aspiration cytology. Diagn Cytopathol 2002; 27: 387-92.

http://dx.doi.org/10.1002/dc.10201

[24] Kessler A, Rappaport Y, Blank A, Marmor S, Weiss J, Graif $M$. Cystic appearance of cervical lymph nodes is characteristic of metastatic papillary thyroid carcinoma. J Clin Ultrasound 2003; 1: 21-5.

http://dx.doi.org/10.1002/jcu.10130

[25] Eustatia-Rutten CF, Corssmit EP, Biermasz NR, Pereira AM, Romijn JA, Smit JW. Survival and death causes in differentiated thyroid carcinoma. J Clin Endocrinold Metab 2006; 91: 313-9.

http://dx.doi.org/10.1210/jc.2005-1322

[26] Patel KN, Shaha AR. Poorly differentiated and anaplastic thyroid cancer. Cancer Control 2006; 13: 119-28

[27] Wiseman SM, Masoudi H, Niblock P, Turbin D, Rajput A, Hay $\mathrm{J}$, et al. Anaplastic thyroid carcinoma: expression profile of targets for therapy offers new insights for disease treatment. Ann Surg Oncol 2007; 14: 719-29.

http://dx.doi.org/10.1245/s10434-006-9178-6

[28] Baldini E, Sorrenti S, D'Armiento E, Guaitoli E, Morrone S, D'Andrea $\mathrm{V}$, et al. Effects of the Aurora kinases pan-inhibitor SNS-314 mesylate on anaplastic thyroid cancer derived cell lines. Clin Ter 2012; 163: e307-13.

[29] Baldini E, Sorrenti S, D'Armiento E, Prinzi N, Guaitoli E, Favoriti $\mathrm{P}$, et al. Aurora kinases: new molecular targets in thyroid cancer therapy. Clin Ter 2012; 163: e457-62.

[30] Antonelli A, Fallahi P, Ulisse S, Ferrari SM, Minuto M, Saraceno G, et al. New targeted therapies for anaplastic thyroid cancer. Anticancer Agents Med Chem 2012; 12: 8793.

http://dx.doi.org/10.2174/187152012798764732

[31] Carhill AA, Cabanillas ME, Jimenez C, Waguespack SG, Habra MA, Hu M, et al. The noninvestigational use of tyrosine kinase inhibitors in thyroid cancer: establishing a standard for patient safety and monitoring. J Clin Endocrinol Metab 2013; 98: 31-42.

http://dx.doi.org/10.1210/jc.2012-2909

[32] Gospodarowicz MK, Henson DE, Hutter RVP, O'Sullivan B, Sobin LH, Wittekind CL. Prognostic factors in cancer 2nd ed. New York: Wiley-Liss 2001

[33] Passler C, Scheuba C, Prager G, Kaczirek K, Kaserer K, Zettinig G, et al. Prognostic factors of papillary and follicular thyroid cancers: differences in an iodine-replete endemic goiter region. Endocr-Relat Cancer 2004; 11: 131-9. http://dx.doi.org/10.1677/erc.0.0110131

[34] Handkiewicz-Junak D, Czarniecka A, Jarząb B. Molecular prognostic markers in papillary thyroid cancer: current status and future directions. Mol Cell Endocrinol 2010; 322: 8-28. http://dx.doi.org/10.1016/i.mce.2010.01.007

[35] Shibru D, Chung KW, Kebebew E. Recent developments in the clinical application of thyroid cancer biomarkers. Curr Opin Oncol 2008; 20: 13-8.

http://dx.doi.org/10.1097/CCO.0b013e3282f27e49

[36] Gharib H. Fine-needle aspiration biopsy of thyroid nodules: advantages, limitations, and effect. Mayo Clin Proceed 1994; 69: 44-9.

http://dx.doi.org/10.1016/S0025-6196(12)61611-5

[37] Hamburger JI. Diagnosis thyroid nodules by fine needle biopsy: use and abuse. J Clin Endocrinol Metab 1994; 79: 335-9.

http://dx.doi.org/10.1210/jc.79.2.335

[38] Baloch ZW, Sack MJ, Yu GH, Livolsi VA, Gupta PK. Fineneedle aspiration of thyroid: an institutional experience. Thyroid 1998; 8: 565-9.

http://dx.doi.org/10.1089/thy.1998.8.565

[39] Cibas ES, Ali SZ. The Bethesda system for reporting thyroid cytopathology. Am J Clin Pathol 2009; 132: 658-65.

http://dx.doi.org/10.1309/AJCPPHLWMI3JV4LA
[40] Baloch ZW, LiVolsi VA, Asa SL, Rosai J, Merino MJ, Randolph G, et al. Diagnostic terminology and morphologic criteria for cytologic diagnosis of thyroid lesions: a synopsis of the National Cancer Institute Thyroid Fine-Needle Aspiration State of the Science Conference. Diagn Cytopathol 2008; 36: 425-37.

\section{http://dx.doi.org/10.1002/dc.20830}

[41] Rago T, Di Coscio G, Basolo F, Scutari M, Elisei R, Berti P, et al. Combined clinical, thyroid ultrasound and cytological features help to predict thyroid malignancy in follicular and Hurtle cell thyroid lesions: results from a series of 505 consecutive patients. Clin Endocrinol 2007; 66: 13-20.

[42] Sorrenti S, Trimboli P, Catania A, Ulisse S, De Antoni E, D'Armiento $M$. Comparison of malignancy rate in thyroid nodules with cytology of indeterminate follicular or indeterminate Hürthle cell neoplasm. Thyroid 2009; 19: 35560.

\section{http://dx.doi.org/10.1089/thy.2008.0338}

[43] Trimboli P, Ulisse S, D'Alò M, Solari F, Fumarola A, Ruggieri $\mathrm{M}$, et al. Analysis of clinical, ultrasound and colour flowDoppler characteristics in predicting malignancy in follicular thyroid neoplasms. Clin Endocrinol 2008; 69: 342-4. http://dx.doi.org/10.1111/j.1365-2265.2007.03158.x

[44] Trimboli P, Sorrenti S. Low value of color flow-doppler in predicting malignancy of thyroid follicular neoplasms. Diagn Cytopathol 2009; 37: 391-2 http://dx.doi.org/10.1002/dc.21050

[45] Trimboli P, Condorelli E, Catania A, Sorrenti S. Clinical and ultrasound parameters in the approach to thyroid nodules cytologically classified as indeterminate neoplasm. Diagn Cytopathol 2009; 37: 783-5. http://dx.doi.org/10.1002/dc.21136

[46] Troncone G, Volante M, laccarino A, Zeppa P, Cozzolino I, Malapelle U, et al. Cyclin D1 and D3 overexpression predicts malignant behaviour in thyroid fine-needle aspirates suspicious for Hurthle cell neoplasms. Cancer 2009; 117: 522-9.

[47] Sapio MR, Posca D, Raggioli A, Guerra A, Marotta V, Deandrea $\mathrm{M}$, et al. Detection of RET/PTC, TRK and BRAF mutations in preoperative diagnosis of thyroid nodules with indeterminate cytological findings. Clin Endocrinol 2007; 66: 678-83.

http://dx.doi.org/10.1111/j.1365-2265.2007.02800.x

[48] Salvatore G, Giannini R, Faviana P, Caleo A, Migliaccio I, Fagin JA, et al. Analysis of BRAF point mutation and RET/PTC rearrangements refines the fine-needle aspiration diagnosis of papillary thyroid carcinoma. J Clin Endocrinol Metab 2004; 89: 5175-80. http://dx.doi.org/10.1210/jc.2003-032221

[49] Leidig-Bruckner G, Cichorowski G, Sattler P, Bruckner T, Sattler B. Evaluation of thyroid nodules-combined use of $99 \mathrm{mTc}$-methylisobutyInitrile scintigraphy and aspiration cytology to assess risk of malignancy and stratify patients for surgical or nonsurgical therapy - a retrospective study. Clin Endocrinol 2012; 76: 749-58. http://dx.doi.org/10.1111/j.1365-2265.2011.04292.x

[50] Deandreis D, Al Ghuzian A, Auperin A, Vielh P, Caillou B Chami $\mathrm{L}$, et al. Is $18 \mathrm{~F}$-fluorodeoxyglucose-PET/CT useful for the presurgical characterization of thyroid nodules with indeterminate fine needle aspiration cytology? Thyroid 2012; 22: $165-72$. http://dx.doi.org/10.1089/thy.2011.0255

[51] Tuttle RM, Lemar H, Burch HB. Clinical features associated with an increased risk thyroid malignancy in patients with follicular neoplasia by fine-needle aspiration. Thyroid 1998; 8: 377-83 http://dx.doi.org/10.1089/thy.1998.8.377

[52] Papale F, Cafiero G, Grimaldi A, Marino G, Rosso F, Mian C, et al. Galectin-3 expression in thyroid fine needle cytology 
(t-FNAC) uncertain cases: validation of molecular markers and technology innovation. J Cell Physiol 2013; 228: 968-74. http://dx.doi.org/10.1002/jcp.24242

[53] Cantisani V, Ulisse S, Guaitoli E, De Vito C, Caruso R, Mocini $R$, et al. Q-elastography in the presurgical diagnosis of thyroid nodules with indeterminate cytology. PLoS One 2012; 7: e50725.

http://dx.doi.org/10.1371/journal.pone.0050725

[54] Melillo RM, Santoro M. molecular biomarkers in thyroid FNA samples. J Clin Endocrinol Metab 2012; 97: 4370-3. http://dx.doi.org/10.1210/jc.2012-3730

[55] Jameson JL. Minimizing unnecessary surgery for thyroid nodules. New Engl J Med 2012; 367: 765-7. http://dx.doi.org/10.1056/NEJMe1205893

[56] Nikiforov YE, Steward DL, Robinson-Smith TM, Haugen BR, Klopper JP, Zhu Z, et al. Molecular testing for mutations in improving the fine-needle aspiration diagnosis of thyroid nodules. J Clin Endocrinol Metab 2009; 94: 2092-8. http://dx.doi.org/10.1210/jc.2009-0247

[57] Nikiforov YE, Ohori NP, Hodak SP, Carty SE, LeBeau SO, Ferris RL, et al. Impact of mutational testing on the diagnosis and management of patients with cytologically indeterminate thyroid nodules: a prospective analysis of 1056 FNA samples. J Clin Endocrinol Metab 2011; 96: 3390-7. http://dx.doi.org/10.1210/jc.2011-1469

[58] Moses W, Weng J, Sansano I, Peng M, Khanafshar E, Ljung $\mathrm{BM}$, et al. Molecular testing for somatic mutations improves the accuracy of thyroid fine-needle aspiration biopsy. World $\mathrm{J}$ Surg 2010; 34: 2589-94. http://dx.doi.org/10.1007/s00268-010-0720-0

[59] Cantara S, Capezzone M, Marchisotta S, Capuano S, Busonero G, Toti $\mathrm{P}$, et al. Impact of proto-oncogene mutation detection in cytological specimens from thyroid nodules improves the diagnostic accuracy of cytology. J Clin Endocrinol Metab 2010; 95: 1365-9.

http://dx.doi.org/10.1210/jc.2009-2103

[60] Chudova D, Wild JI, Wang ET, Wang H, Rabbee N, Egidio $\mathrm{CM}$, et al. Molecular classification of thyroid nodules using high-dimensionality genomic data. J Clin Endocrinol Metab 2010; 95: 5296-304.

http://dx.doi.org/10.1210/jc.2010-1087

[61] Alexander EK, Kennedy GC, Baloch ZW, Cibas ES, Chudova $\mathrm{D}$, Diggans $\mathrm{J}$, et al. Preoperative diagnosis of benign thyroid nodules with indeterminate cytology. N Engl J Med 2012; 367: 705-15.

http://dx.doi.org/10.1056/NEJMoa1203208

[62] Walsh PS, Wild JI, Tom EY, Reynolds JD, Chen DC, Chudova DI, et al. Analytical performance verification of a molecular diagnostic for cytology-indeterminate thyroid nodules. J Clin Endocrinol Metab 2012; 97: E2297-306. http://dx.doi.org/10.1210/jc.2012-1923

[63] Kwak JY, Kim E-K. Indeterminate thyroid nodules-added testing, added value? Nat Rev Endocrinol 2013. http://dx.doi.org/10.1038/nrendo.2013.79

[64] Kloos, RT, Wilde JI, Tom EY, Pagan M, et al. Does addition of BRAF V600E Mutation testing modify sensitivity or specificity of the Afirma gene expression classifier in cytologically indeterminate thyroid nodules? J Clin Endocrinol Metab 2013; doi.org/10.1210/jc.2012-3762

[65] Lodewijk L, Prins AM, Kist JW, Walk GD, Kranenburg O, Borel Rinkes IHM, et al. The value of miRNA in diagnosing thyroid cancer: a systematic review. Cancer Biomarkers 2012; 11: 229-38.

[66] American Thyroid Association Guidelines Task Force, Kloos RT, Eng C, Evans DB, Francis GL, Gagel RF, et al. Medullary thyroid cancer: management guidelines of the American Thyroid Association. Thyroid 2009; 19: 565-612. http://dx.doi.org/10.1089/thy.2008.0403

[67] Baldini E, Sorrenti S, Catania A, Guaitoli E, Prinzi N, Mocini $\mathrm{R}$, et al. Diagnostic utility of thyroglobulin measurement in the fine needle aspirates from cervical lymph nodes: a case report. G Chir 2012; 33: 387-91.

[68] Salmaslıoğlu A, Erbil Y, Cıtlak G, Ersöz F, Sarı S, Olmez A et al. Diagnostic value of thyroglobulin measurement in fineneedle aspiration biopsy for detecting metastatic lymph nodes in patients with papillary thyroid carcinoma. Langenbecks Arch Surg 2011; 396: 77-81. http://dx.doi.org/10.1007/s00423-010-0723-1

[69] Kim MJ, Kim EK, Kim BM, Kwak JY, Lee EJ, Park CS, et al. Thyroglobulin measurement in fine-needle aspirate washout: the criteria for neck node dissection for patients with thyroid cancer. Clin Endocrinol 2009; 70: 145-51. http://dx.doi.org/10.1111/j.1365-2265.2008.03297.x

[70] Bournaud C, Charrié A, Nozières C, Chikh K, Lapras V, Denier ML, et al. Thyroglobulin measurement in fine-needle aspirates of lymph nodes in patients with differentiated thyroid cancer: a simple definition of the threshold value, with emphasis on potential pitfalls of the method. Clin Chem Lab Med 2010; 48: 1171-7. http://dx.doi.org/10.1515/cclm.2010.220

[71] Sohn YM, Kim MJ, Kim EK, Kwak JY. Diagnostic performance of thyroglobulin value in indeterminate range in fine needle aspiration washout fluid from lymph nodes of thyroid cancer. Yonsei Med J 2012; 53: 126-31. http://dx.doi.org/10.3349/ymj.2012.53.1.126

[72] Pacini F, Fugazzola L, Lippi F, Ceccarelli C, Centoni R, Miccoli $\mathrm{P}$, et al. Detection of thyroglobulin in fine needle aspirates of nonthyroidal neck masses: a clue to the diagnosis of metastatic differentiated thyroid cancer. J Clin Endocrinol Metab 1992; 74: 1401-4. http://dx.doi.org/10.1210/jc.74.6.1401

[73] Frasoldati A, Toschi E, Zini M, Flora M, Caroggio A, Dotti C et al. Role of thyroglobulin measurement in fine-needle aspiration biopsies of cervical lymph nodes in patients with differentiated thyroid cancer. Thyroid 1999; 9: 105-11. http://dx.doi.org/10.1089/thy.1999.9.105

[74] Cignarelli M, Ambrosi A, Marino A, Lamacchia O, Campo M Picca G, et al. Diagnostic utility of thyroglobulin detection in fine-needle aspiration of cervical cystic metastatic lymph nodes from papillary thyroid cancer with negative cytology. Thyroid 2003; 13: 1163-7.

http://dx.doi.org/10.1089/10507250360731578

[75] Pomorski L, Kaczka K, Piaskowski S, Wójcik I, Rieske P, Matejkowska M, et al. Detection of lymph node metastases of papillary thyroid cancer - comparison of the results of histopathology, immunohistochemistry and reverse transcription-polymerase chain reaction - a preliminary report. Langenbecks Arch Surg 2005; 390: 209-15. http://dx.doi.org/10.1007/s00423-004-0528-1

[76] Snozek CL, Chambers EP, Reading CC, Sebo TJ, Sistrunk JW, Singh RJ, et al. Serum thyroglobulin, high-resolution ultrasound, and lymph node thyroglobulin in diagnosis of differentiated thyroid carcinoma nodal metastases. J Clin Endocrinol Metab 2007; 92: 4278-81.

\section{http://dx.doi.org/10.1210/jc.2007-1075}

[77] Borel AL, Boizel R, Faure P, Barbe G, Boutonnat J, Sturm N et al. Significance of low levels of thyroglobulin in fine needle aspirates from cervical lymph nodes of patients with a history of differentiated thyroid cancer. Eur J Endocrinol 2008; 158: $691-8$

http://dx.doi.org/10.1530/EJE-07-0749

[78] Baskin HJ. Detection of recurrent papillary thyroid carcinoma by thyroglobulin assessment in the needle washout after fineneedle aspiration of suspicious lymph nodes. Thyroid 2004; 14: 959-63.

http://dx.doi.org/10.1089/thy.2004.14.959

[79] Cunha N, Rodrigues F, Curado F, Ilhéu O, Cruz C, Naidenov $\mathrm{P}$, et al. Thyroglobulin detection in fine-needle aspirates of cervical lymph node: a technique for the diagnosis of 
metastatic differentiated thyroid cancer. Eur $\mathrm{J}$ Endocrinol 2007; 157: 101-7.

http://dx.doi.org/10.1530/EJE-07-0088

[80] Kim DW, Jeon SJ, Kim CG. Usefulness of thyroglobulin measurement in needle-washout of fine-needle aspiration biopsy for the diagnosis of cervical lymph node metastases from papillary thyroid cancer before thyroidectomy. Endocrine 2012; 42: 399-403.

http://dx.doi.org/10.1007/s12020-012-9636-9

[81] Baldini E, Sorrenti S, Di Gioia C, De Vito C, Antonelli A, Gnessi $L$, et al. Cervical lymph node metastases from thyroid cancer: does thyroglobulin and calcitonin measurement in fine needle aspirates improve the diagnostic value of cytology? BMC Clin Pathol 2013; $13: 7$. http://dx.doi.org/10.1186/1472-6890-13-7

[82] Boi F, Baghino G, Atzeni F, Lai ML, Faa G, Mariotti S: The diagnostic value for differentiated thyroid carcinoma metastases of thyroglobulin $(\mathrm{Tg})$ measurement in washout fluid from fine-needle aspiration biopsy of neck lymph node is maintained in presence of circulating anti- $\mathrm{Tg}$ antibodies. $\mathrm{J}$ Clin Endocrinol Metab 2006; 91: 1364-9.

http://dx.doi.org/10.1210/jc.2005-1705

[83] 2009 AJCC cancer staging manual. $7^{\text {th }}$ ed. New York: Springer-Verlag 2009.

[84] Pacini F, Castagna MG, Brilli L, Pentheroudakis G, on behalf of the ESMO guidelines working group. Thyroid cancer: ESMO clinical practice guidelines for diagnosis treatment and follow-up. Ann Oncol 2012; 23: vii110-9. http://dx.doi.org/10.1093/annonc/mds230

[85] Castagna MG, Maino F, Cipri C, Belardini V, Theodoropoulou A, Cevenini G, et al. Delayed risk stratification, to include the response to initial treatment (surgery and radioiodine ablation), has better outcome predictivity in differentiated thyroid cancer patients. Eur J Endocrinol 2011; 165: 441-6. http://dx.doi.org/10.1530/EJE-11-0466

[86] Xing M. BRAF mutation in papillary thyroid cancer: pathogenic role, molecular bases, and clinical implications. Endocr Rev 2007; 28: 742-62. http://dx.doi.org/10.1210/er.2007-0007

[87] Handkiewicz-Junak D, Czarniecka A, Jarząb B. Molecular prognostic markers in papillary thyroid cancer: current status and future directions. Mol Cell Endocrinol 2010; 322: 8-28. http://dx.doi.org/10.1016/j.mce.2010.01.007

[88] Shibru D, Chung KW, Kebebew E. Recent developments in the clinical application of thyroid cancer biomarkers. Curr Opin Oncol 2008; 20: 13-8.

http://dx.doi.org/10.1097/CCO.0b013e3282f27e49

[89] Guerra A, Sapio MR, Marotta V, Campanile E, Rossi S, Forno I, et al. The Primary Occurrence of BRAFV600E Is a Rare Clonal Event in Papillary Thyroid Carcinoma. J Clin Endocrinol Metab 2012; 97: 517-24.

http://dx.doi.org/10.1210/jc.2011-0618

[90] Ito Y, Yoshida H, Maruo R, Morita S, Takano T, Hirokawa M, et al. BRAF mutation in papillary thyroid carcinoma in a Japanese population: its lack of correlation with high-risk clinicopathological features and disease-free survival of patients. Endocrine J 2009; 56: 89-97. http://dx.doi.org/10.1507/endocri.K08E-208

[91] Ulisse S, Baldini E, Sorrenti S, Barollo S, Prinzi N, Catania A, et al. In papillary thyroid carcinoma BRAFV600E is associated with increased expression of the urokinase plasminogen activator and its cognate receptor, but not with disease-free interval. Clin Endocrinol 2012; 77: 780-6. http://dx.doi.org/10.1111/j.1365-2265.2012.04465.x

[92] Chou CK, Yang KD, Chou FF, Huang CC, Lan YW, Lee YF, et al. Prognostic implications of miR-146b expression and its functional role in papillary thyroid carcinoma. J Clin Endocrinol Metab 2013; 98: E196-205. http://dx.doi.org/10.1210/jc.2012-2666
[93] Ulisse S, Baldini E, Sorrenti S, Barollo S, Gnessi L, Catania $A$, et al. High expression of the urokinase plasminogen activator and its cognate receptor associates with advanced stages and reduced disease-free interval in papillary thyroid carcinoma. J Clin Endocrinol Metab 2011; 96: 504-8. http://dx.doi.org/10.1210/jc.2010-1688

[94] Buergy D, Weber T, Maurer GD, Mudduluru G, Medved F, Leupold $\mathrm{JH}$, et al. Urokinase receptor, MMP-1 and MMP-9 are markers to differentiate prognosis, adenoma and carcinoma in thyroid malignancies. Int J Cancer 2009; 125: 894-901.

http://dx.doi.org/10.1002/ijc.24462

[95] Ulisse S, Baldini E, Toller M, Marchioni E, Giacomelli L, De Antoni E, et al. Differential Expression of the Components of the Plasminogen Activating System in Human Thyroid Tumor Derived Cell Lines and Papillary Carcinomas. Eur J Cancer 2006; 42: 2631-8.

http://dx.doi.org/10.1016/j.ejca.2006.04.017

[96] Horvatić Herceg G, Herceg D, Kralik M, Bence-Zigman Z, Tomić-Brzac $\mathrm{H}$, Kulić A. Urokinase-Type Plasminogen Activator and its Inhibitor in Thyroid Neoplasms: a Cytosol Study. Wien Klin Wochenschr 2006; 118: 601-9.

http://dx.doi.org/10.1007/s00508-006-0703-1

[97] Sid B, Langlois B, Sartelet H, Bellon G, Dedieu S, Martiny L. Thrombospondin-1 enhances human thyroid carcinoma cell invasion through urokinase activity. Int $\mathrm{J}$ Biochem Cell Biol 2008; 40: 1890-900.

http://dx.doi.org/10.1016/i.biocel.2008.01.023

[98] Chu QD, Hurd TC, Harvey S, Martinick M, Markus G, Tan D, et al. Overexpression of urinary plasminogen activator (UPA) protein and mRNA in thyroid carcinogenesis. Diag Mol Pathol 2004; 13: 241-6. http://dx.doi.org/10.1097/01.pdm.0000137100.26010.64

[99] Sid B, Dedieu S, Delorme N, Sartelet H, Rath GM, Bellon G, et al. Human thyroid carcinoma cell invasion is controlled by the low density lipoprotein receptor-related protein-mediated clearance of urokinase plasminogen activator. Int $\mathrm{J}$ Biochem Cell Biol 2006; 38: 1729-40.

http://dx.doi.org/10.1016/j.biocel.2006.04.005

[100] Ito $\mathrm{Y}$, Takeda T, Kobayashi T, Wakasugi E, Tamaki $\mathrm{Y}$, Umeshita $\mathrm{K}$, et al. Plasminogen Activation System in Active Even in Thyroid Tumors; an Immunohistochemical Study. Anticancer Res 1996; 16: 81-9.

[101] Kim SJ, Shiba E, Taguchi T, Tsukamoto F, Miyoshi Y, Tanji $\mathrm{Y}$, et al. uPA Receptor Expression in Benign and Malignant Thyroid Tumors. Anticancer Res 2002; 22: 387-93.

[102] Smit JW, van der Pluijm G, Romijn HA, Löwik CW, Morreau $\mathrm{H}$, Goslings BM. Degradation of extracellular matrix by metastatic follicular thyroid carcinoma cell lines: role of the plasmin activation system. Thyroid 1999; 9: 913-9. http://dx.doi.org/10.1089/thy.1999.9.913

[103] Baldini E, Sorrenti S, D'Armiento E, Di Matteo FM, Catania A, Ulisse $S$. The urokinase plasminogen activating system in thyroid cancer: clinical implications. G Chir 2012; 33: 305-10.

[104] Nowicki TS, Kummer NT, lacob C, Suslina N, Schaefer S, Schantz $\mathrm{S}$, et al. Inhibition of UPAR and UPA reduces invasion in papillary thyroid carcinoma cells. Laryngoscope 2010; 120: 1383-90.

http://dx.doi.org/10.1002/lary.20915

[105] Nowicki TS, Zhao H, Darzynkiewicz Z, Moscatello A, Shin E, Schantz $S$, et al. Downregulation of UPAR inhibits migration, invasion, proliferation, FAK/PI3K/Akt signaling and induces senescence in papillary thyroid carcinoma cells. Cell Cycle 2011; 10: 100-7.

http://dx.doi.org/10.4161/cc.10.1.14362

[106] Packman KS, Demeure MJ, Doffek KM, Wilson SD. Increased Plasminogen Activator and Type IV Collagenase Activity in Invasive Follicular Thyroid Carcinoma Cells. Surgery 1995; 118: 1011-6.

http://dx.doi.org/10.1016/S0039-6060(05)80107-2 
[107] Baldini E, Toller M, Graziano FM, Russo FP, Pepe M, Biordi $\mathrm{L}$, et al. Expression of matrix metalloproteinases and their specific inhibitors (TIMPs) in normal and different human thyroid tumor cell lines. Thyroid 2004; $14: 881-8$.

http://dx.doi.org/10.1089/thy.2004.14.881

[108] Nowicki TS, Moscatello AL, Shin E, Schantz S, Tiwary RK, Geliebter J. The urokinase plasminogen activator system in metastatic papillary thyroid carcinoma: a potential therapeutic target. J Clin Endocrinol Metab 2011; 96: 3062-4. http://dx.doi.org/10.1210/jc.2011-1123

[109] Ulisse S, Baldini E, Sorrenti S, D'Armiento M. The urokinase plasminogen activator system: a target for anti-cancer therapy. Curr Cancer Drug Tar 2009; 9: 32-71. http://dx.doi.org/10.2174/156800909787314002

[110] Duffy MJ. The urokinase plasminogen activator system: role in malignancy. Curr Pharm Des 2004; 10: 39-49. http://dx.doi.org/10.2174/1381612043453559

[111] Jänicke F, Prechtl A, Thomssen C, Harbeck N, Meisner C, Untch $\mathrm{M}$, et al. Randomized Adjuvant Chemotherapy Trial in High-risk, Lymph Node-negative Breast Cancer Patients Identified by Urokinase-type Plasminogen Activator and Plasminogen Activator Inhibitor Type 1. J Natl Cancer Inst 2001; 93: 913-20.

http://dx.doi.org/10.1093/jnci/93.12.913

[112] Duffy MJ. Urokinase-type plasminogen activator: a potent marker of metastatic potential in human cancer. Biochem Soc Trans 2002; 30: 207-10. http://dx.doi.org/10.1042/BST0300207

[113] Schmitt M, Harbeck N, Thomssen C, Wilhelm O, Magdolen $\mathrm{V}$, Reuning $\mathrm{U}$, et al. Clinical impact of the plasminogen activation system in tumor invasion and metastasis: prognostic relevance and target for therapy. Thromb Haemost 1997; 78: 285-96.

[114] Look MP, van Putten WL, Duffy MJ, Harbeck N, Christensen IJ, Thomssen C, et al. Pooled Analysis of Prognostic Impact of Urokinase-type Plasminogen Activator and its Inhibitor PAI-1 in 8377 Breast Cancer Patients. J Natl Cancer Inst 2002; 94: 116-28. http://dx.doi.org/10.1093/jnci/94.2.116

[115] Foekens JA, Peters HA, Look MP, Portengen H, Schmitt M, Kramer MD, et al. The Urokinase System of Plasminogen Activation and Prognosis in 2780 Breast Cancer Patients. Cancer Res 2000; 60: 636-43.

[116] Harris L, Fritsche H, Mennel R, Norton L, Ravdin P, Taube S, Somerfield MR, Hayes DF, Bast RC Jr, American Society of Clinical Oncology. American Society of Clinical Oncology 2007 update of recommendations for the use of tumor markers in breast cancer. J Clin Oncol 2007; 25: 5287-312. http://dx.doi.org/10.1200/JCO.2007.14.2364
[117] Heikkilä A, Hagström J, Mäenpää H, Louhimo J, Siironen P, Heiskanen I, et al. Loss of estrogen receptor Beta expression in follicular thyroid carcinoma predicts poor outcome. Thyroid 2013; 23: 456-65.

http://dx.doi.org/10.1089/thy.2012.0363

[118] Ali S, Coombes RC. Estrogen receptor alpha in human breast cancer: occurrence and significance. J Mammary Glang Biol Neoplasia 2000; 5: 271-81. http://dx.doi.org/10.1023/A:1009594727358

[119] Halon A, Nowak-Markwitz E, Maciejczyk A, Pudelko M, Gansukh T, Gyorffy B, et al. Loss estrogen receptor beta expression correlates with shorter overall survival and lack of clinical response to chemiotherapy in ovarian cancer patients. Anticancer Res 2011; 31: 711-8.

[120] Kawai H, Ishii A, Washiya K, Konno T, Kon H, Yamaya C, et al. Estrogen receptor alpha and beta are prognostic factors in non-small cell lung cancer. Clin Cancer Res 2000; 11: 50849. http://dx.doi.org/10.1158/1078-0432.CCR-05-0200

[121] Omoto $\mathrm{Y}$, Inoue S, Ogawa S, Toyama T, Yamashita H, Muramatsu $\mathrm{M}$, et al. Clinical value of wild-type estrogen receptor beta expression in breast cancer. Cancer Lett 2001; 163: 207-12. http://dx.doi.org/10.1016/S0304-3835(00)00680-7

[122] Halon A, Materna V, Drag-Zalesinska M, Nowak-Markwitz E, Gansukh T, Donizy $\mathrm{P}$, et al. Estrogen receptor alpha expression in ovarian cancer predicts longer survival. Pathol Oncol Res 2011; 17: 511-8. http://dx.doi.org/10.1007/s12253-010-9340-0

[123] Mauro LV, Dalurzo M, Carlini MJ, Smith D, Nunez M, Simian $\mathrm{M}$, et al. Estrogen receptor beta and epidermal growth factor receptor as early-stage prognostic biomarkers of non-small cell lung cancer. Oncol Rep 2010; 24: 1331-8.

[124] de la Chapelle A, Jazdzewski K. MicroRNAs in thyroid cancer. J Clin Endocrinol Metab 2011; 96: 3326-36. http://dx.doi.org/10.1210/jc.2011-1004

[125] Nikiforova MN, Tseng GC, Steward S, Diorio D, Nikiforov YE. MicroRNA Expression Profiling of Thyroid Tumors: Biological Significance and Diagnostic Utility. J Clin Endocrinol Metab 2008; 93: 1600-8.

http://dx.doi.org/10.1210/jc.2007-2696

[126] Chou CK, Chen RF, Chou FF, Chang HW, Chen YJ, Lee YF, et al. miR-146b is highly expressed in adult papillary thyroid carcinomas with high risk features including extrathyroidal invasion and the BRAF(V600E) mutation. Thyroid 2010; 20: 489-94.

http://dx.doi.org/10.1089/thy.2009.0027

(c) 2013 Baldini et al.; Licensee Savvy Science Publisher.

This is an open access article licensed under the terms of the Creative Commons Attribution Non-Commercial License (http://creativecommons.org/licenses/by-nc/3.0/) which permits unrestricted, non-commercial use, distribution and reproduction in any medium, provided the work is properly cited. 